\title{
Ensuring Effectiveness of Economic and Monetary Policies through Considering Economic Schools of Thought: Lebanon 1990-2010
}

\author{
Georges N. Nehme \\ Faculty of Business Administration, Antonine University, Baabda, Lebanon \\ Email: g.n.nehme@gmail.com
}

Received 18 December 2013; revised 28 January 2014; accepted 9 February 2014

Copyright (C) 2014 by author and Scientific Research Publishing Inc. This work is licensed under the Creative Commons Attribution International License (CC BY). http://creativecommons.org/licenses/by/4.0/

(c) (i) Open Access

\begin{abstract}
Decision makers and executives should have a macroeconomic approach in planning and fixing economic and monetary policies for their countries. A national economy should be considered as a system including three interdependent markets: Financial market, Labor market, and Goods and Services market. Any attempt to practice an economic or monetary policy emphasizing on one or two of these markets and neglecting the third will lead to public debts, high unemployment and/or inflation rates. This neglect will also increase the financial crises risk especially for developing countries. These developing countries are suffering from being not able to apply liberal policies, compete in the international multilateral trade system, and benefit from globalization. Why Lebanese government is still insisting on applying liberal policies, high tax rate, low government expenses and investments, fixed exchange rate, and high interest rate? Is it reasonable and possible to have a developed financial market with bank deposits equaling three times the Lebanese GDP, and at the same time, a very weak labor and goods and services markets characterized by $18 \%$ unemployment rate and a very low consumers' purchasing power? How does Lebanon have a huge public debt equaling twice its national GDP and be considered by the IMF as the fourth country in economic growth progression in the region? Why not considering Mundell's incompatibility triangle and Kaldor's magic square to analyze this critical economic situation? Is switching from a currency board to a forward-looking crawling PEG one of the factors to break this vicious circle?
\end{abstract}

\section{Keywords}

Unemployment; Economic Growth; Inflation; Interest Rate; Exchange Rate 


\section{Introduction}

During the twentieth century, economic sciences and policy practices had been dominated by a bipolar epistemological opposition between capitalism and socialism.

Nowadays, explicit references to Liberalism and Marxism are becoming less frequent than they were before; these models became incompatible with the new international economic trends. Economists, researchers and executives are trying to emphasize on new intermediate models avoiding weaknesses of both extremes. Divergences in applying intermediate models depend on the intervening scales that are adopted in different countries.

Market economies are not regulated by Adam Smith's invisible hand, they are affected by governments' behavior based on complex mechanisms and organized according to inherited practices and economic doctrines of the persons in charge. For many social democrats, the economy is controlled by human beings but not abstract forces [1].

For Capitalism pretenders and supporters, applying a capitalist model can be justified by the fact that it is unaffected by political power and political developments.

Intermediate models adopted by some governments are either tolerant of unemployment or tolerant of inflation. Governments should justify their political orientation in ensuring the country's best interests. The main difference between social democrats' and conservative liberals' behavior is based on the importance and the focus attributed to either macroeconomic or microeconomic approaches [2].

Usually liberals consider that maintaining price stability is the main responsibility of macroeconomic authorities. Social democrats consider that growth and employment are the core macroeconomic objectives, while inflation is a microeconomic problem, "thus social democrat policies cannot succeed unless social actors are able to limit the inflationary impact of expansionist policies by keeping a grip on real wages" [3].

Social democrats stress on implementing political expansionism through improvement of productivity, high-wage policy and monetary policies' impact on the real economy ${ }^{1}$.

Liberals stress on restrictive policies. They always say that inflation has a negative impact on everybody and they implement restrictive monetary policy to decrease inflation rate. At the same time, they believe that money is neutral. For Verley, "this is rather contradictory coming from people who generally affect to believe that money is neutral and that monetary policy can never be used as a lever to influence the real economy".

For liberal economists, the market law of demand and supply regulates prices and quantities for everything except money. If we go back and reconsider the general titles attributed to different ideologies and doctrines, it is worth to ask and think that why a monetary policy that considers the effective exchange rate to be considered liberal and less interventionist than an economic policy seeking employment.

The main epistemological question remains on evaluating the intermediate practices, trying to explain why regulation policies or liberal policies should have succeeded or failed in different time periods [4].

\section{Lebanon}

After the end of the civil war in 1990, the Lebanese infrastructure was completely destroyed, the government needed to rebuild the economy and the country's infrastructure. Many financial weaknesses faced the government policy which requires high level of expenditures for the targeted recovery. The government had low tax income and huge fiscal deficit, thus, executives decided to ensure necessary funding through public borrowing from the Lebanese banking sector.

The government strategy targeted the development of the tourism sector, the attraction of investments and capital, and expected high income to pay back the banking sector.

It is obvious that economists who were in charge of the government policy and strategy, focused on intermediate economic model close to liberalism, capitalism and market economy with absence and weaknesses of the government intervention in regulating different markets.

Unfortunately, and because of political insecurity and regional military conflicts and wars, the government strategy couldn't attract foreign investments and didn't achieve high investment returns. Accordingly, public debts increased progressively, successive governments were incapable to pay it back, and were obliged to borrow more to pay the annual debt service to local banks.

Economic sciences are characterized by structural divergences and lack of consensus in all concepts, theories,

${ }^{1}$ For socialists, money is not neutral. 
models, policies and applications due to the epistemological division between different schools of thought mainly, the classical and the Keynesian.

Lebanese decision makers and executives should have had a macroeconomic approach in planning and fixing economic and monetary policies for their country. Their macroeconomic approach should have been based on considering the economy as a system not as a group of markets. A national economy should be considered as a system including three interdependent markets: Financial market, Labor market and Goods and Services market. Any attempt to practice an economic or monetary policy emphasizing on one or two of these markets and neglecting the third will lead to public debts, high unemployment and/or inflation rates. This neglect will also increase the financial crises risk especially for developing countries. These developing countries are suffering from not being able to apply liberal policies, to compete in the international multilateral trade system and to benefit from globalization. Lebanese governments were and are still emphasizing on the equilibrium of their financial market targeting essentially the price stability through practicing liberal policies based on tourism, services, strong banking sector and neglecting the real productive sectors mainly industry and agriculture.

After the 1973 financial crisis, many economists and decision makers considered that inflation was due to the practice of the economy of demand based on increasing salaries and decreasing interest rates. They decided to switch again to classic theories practiced before 1929 with important modifications through monetarism and neoclassical theories developed later by international economists, mainly Milton Friedman.

Their Major concerns were based on decreasing fiscal deficit and inflation through practicing restrictive budget and monetary policies and a fixed exchange rate.

Lebanese decision makers neglected the impact of such policies on consumption, salaries, employment and thus on production and real economic growth.

The exclusive Lebanese focus on the financial market and the neglect of the structural interdependence with other markets, has led to a critical economic situation with structural contradiction. On one hand, Lebanon is achieving very good results and indicators in banking, real estate, economic growth and a positive balance of payment account. On the other hand, Lebanese economy is suffering from unemployment, weaknesses of productive sectors, low consumers' purchasing power, low demand, huge public debt, trade deficit and high interest rate. Lebanese economy can be represented through a vicious circle characterized by positive and negative indicators.

\subsection{Positive Indicators}

In May 2010, the IMF considered that Lebanese economic growth ${ }^{2}$ is the fourth in the Middle East region and one of the highest growths in the world. It has $3.5 \%$ surplus of the balance of payments ${ }^{3}$, moderate inflation average $^{4}$. Its strong reserve in foreign currencies ${ }^{5}$ ensured a fix exchange rate, strong banking sector with high amount of bank deposits ${ }^{6}$.

\subsection{Negative Indicators}

Currently, in 2010, the Lebanese economy is suffering from a high unemployment rate, high dollarization rate, high interest rate ${ }^{7}$, huge public $\mathrm{debt}^{8}$, low consumption and purchasing power, restrictive budget and monetary policies, weak market regulation, no indexation between wages and inflation ${ }^{9}$, fiscal deficit ${ }^{10}$ and trade deficit ${ }^{11}$.

Facing this contradiction and co-habitation between positive and negative indicators characterizing the Lebanese economy, it is important to question the Lebanese reality that includes many theoretical economic contradictions:

How can economists explain the correlation between the increase of bank deposits and the increase of public

\footnotetext{
${ }^{2}$ Lebanese GDP achieved 9\% growth in 2009.

${ }^{3} 7$ billion dollars annual capital entry from Lebanese immigrants.

${ }^{4} 5 \%$ Inflation average for the last 5 years.

${ }^{5}$ Foreign currencies reserve attained 30 billion dollars in March 2010, a historical Lebanese record.

${ }^{6}$ Bank deposits attained a historical record for Lebanon in May 2010, 106 billion dollars equalizing three times the Lebanese GDP.

${ }^{7} 18 \%$ unemployment rate, $64 \%$ dollarization rate of bank deposits, $7 \%$ high average interest rate.

${ }^{8} 55$ billion dollars public debt equals twice the Lebanese GDP.

${ }^{9} 10$ years without any increase of the minimum wage facing $5 \%$ average inflation rate per year.

${ }^{10}$ Fiscal deficit attained $25 \%$ in 2010 , equals to the annual debt service.

${ }^{11} 9$ billion dollars trade deficit due to the weakness of agriculture and industrial productive sectors.
} 
debts? The increase of liquidity and the increase of unemployment? The high economic growth and the high unemployment rate? This situation doesn't respect theoretical principles and models in Economic History.

Decision makers should have worked in a macroeconomic framework including economic variables and indicators. These variables and indicators are characterized by a scientific logical coherence taking into consideration how they hierarchize objectives when not all of them can be equally attained.

The following economic models based on a simple analytical framework can contribute in explaining this contradictory economic situation through model analysis and theoretical transposition into Lebanese reality:

$\Rightarrow$ Kaldor's magic square.

$\Rightarrow$ Hicks's IS-LM curve.

$\Rightarrow$ Mundell's incompatibility triangle.

\section{Kaldor's Magic Square}

Nicholas Kaldor focused on the attainment of four economic objectives: full employment, economic growth, price stability and favorable trade balance. Kaldor has noticed that one of these four objectives will always be incompatible with the others. In economic history, full employment and economic growth cannot be attained with price stability. Price stability and favorable trade balance cannot be realized concurrently [5].

In Lebanon, Decision makers focused exclusively on the financial market with one principal objective: price stability. With a first and quick review of Kaldor's magic square, we can conclude that governments sacrificed full employment and a favorable trade balance but achieved high economic growth and relative price stability.

However, a full macroeconomic analysis of the Lebanese situation clearly shows that Governments strategy and policy didn't achieve any of Kaldor's four objectives. In fact, Lebanon is not benefiting from liberal policies to achieve price stability. Even though inflation is moderate in 2009, as per Table 1; Lebanon lived an $11 \%$ inflation rate in 2010. In addition, Lebanese workers suffered from wage stability for ten consecutive years without any indexation between inflation and wages. Accordingly, Lebanese economy is characterized by a low consumption and a low consumers' purchasing power.

As for economic growth, despite the Fact that IMF considered Lebanon as the fourth country in economic growth evolution in the region; economic history cannot explain the highest economic growth rate concurrently with the highest unemployment rate. In Macroeconomics, it is an artificial Lebanese economic growth, based on real estate sector that employs foreign workers and consists of the third of Lebanese GDP ${ }^{12}$. Thus, this high economic growth did not reflect the growth of the Lebanese productive sectors and did not have any positive effect on Lebanese workers and consumers.

\section{Hicks's IS-LM Curve}

IS-LM is a Keynesian model ${ }^{13}$ exposing the equilibrium in both goods and services market and money market in relation with national income and interest rate.

The equilibrium in both markets can give a general idea about the country's policy mix including both monetary and budgetary policy. Four policy mix models are possible; each combination depends on the type of poli$\mathrm{cy}^{14}$ practiced by the government and the central bank.

A full macroeconomic cooperation between government and central bank is a precondition for enabling government to fulfill its political objectives without compromising the macroeconomic situation and avoiding the recession risks [7].

Two instructive experiences can be taken from economic history as learning models. The first one has been adopted in Germany starting 1990 after its reunification between east and west parts. The Deutch government decided to apply an expansionist budget policy to achieve specific political objectives. The government wanted

Table 1. Kaldor's magic square including Lebanese macroeconomic indicators for 2009 [6].

\begin{tabular}{cc}
\hline Unemployment (18\%) & Economic Growth $(9 \%)$ \\
Inflation $(2.5 \%)$ & Trade Deficit $(21.5 \%)$ \\
\hline
\end{tabular}

\footnotetext{
${ }^{12}$ Real estate sales amount in 2009 attained 9 billion dollars.

${ }^{13}$ Developed by Keynesian economist John Hicks.

${ }^{14}$ Government can apply restrictive or expansionist budget policy, central bank can apply restrictive or expansionist monetary policy.
} 
to support enterprises located in East Germany to enable them improve their productivity, gain competitive advantage and compete in the international market. German government didn't cooperate and discuss its strategy with Bundesbank ${ }^{15}$ representatives who decided to apply accordingly a restrictive monetary policy based on increasing interest rate to avoid inflation consequence. This non cooperative policy mix didn't permit the government to achieve its goals and objectives. Germany passed by a critical economic period that affected different European countries through domino effect.

Another instructive set of policy mix has been implemented in the United States of America in the 1990s via constructive cooperation between former President of the United States, Bill Clinton and the Governor of the Federal Reserve Bank ${ }^{16}$, Alan Greenspan.

President Clinton wanted to decrease the fiscal deficit through a restrictive budget policy based on increasing taxes and decreasing government expenditures. Clinton's economic team knew that applying a restrictive budget policy will affect negatively the consumption, demand and purchasing power and consequently this will increase the recession risk. A full cooperation with Alan Greenspan ${ }^{17}$ enabled Clinton administration to achieve its political objectives illustrated in Figure 1. The fiscal deficit has been reduced. Concurrently, Greenspan applied an expansionist monetary policy, decreased the interest rate and provide necessary liquidity in markets to ensure same level of investment and consumption [7].

This policy mix can be considered as one of the best combination and cooperation between governments and Central Banks.

Successive Lebanese governments from 1990 till 2010, neglected the economy of demand, focused on ensuring price stability through applying a fixed exchange rate, a high interest rate, and didn't focus on labor market. Unemployment attained one of the highest rates in the world; wages were not indexed to inflation. Further to fiscal deficit, governments started public borrowing from local commercial banks. Governments applied restrictive budget policies based on increasing tax rates and decreasing government expenditures. Decision makers introduced a $10 \%$ value added tax in 2000 , increased tax on fuel consumption up to $40 \%$, decreased government expenditures via limited budgets accorded to productive sectors ${ }^{18}$. Governments couldn't pay back the public debt to commercial banks; consequently they were obliged to borrow more to pay public debt services that attain $30 \%$ of the national expenditures. Public administrations were inefficient ${ }^{19}$ and government failed in privatizing them due to political divergences and instability.

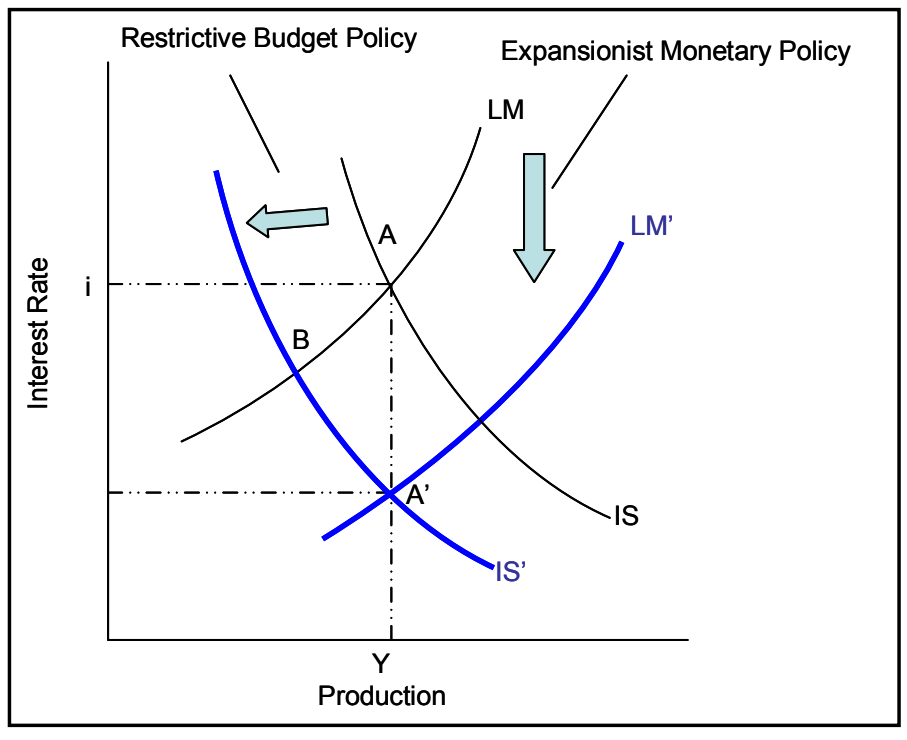

Figure 1. Clinton-Greenspan policy mix [7].

\footnotetext{
${ }^{15}$ Central Bank of Germany.

${ }^{16}$ Central Bank of the United States.

${ }^{17}$ Clinton and Greenspan disregarded their political objectives as democrat and republican and applied a strong macroeconomic cooperation between US government and Federal Reserve Bank.

${ }^{18}$ Agriculture and Industry ministries got limited budget enabling them paying employees' wages without any investment capacity.

${ }^{19}$ Lebanese Electricity Company scored an annual deficit equalizing $10 \%$ of Government expenditures.
} 
A macroeconomic analysis of government budget policy combined with the Central Bank monetary policy clearly shows, as per Figure 2, that the adopted policy mix was rudely restrictive and didn't took into consideration consumption, demand and employment.

According to IS-LM model, a restrictive policy mix will result in a high interest rate and a low national income. In comparing it with the Clinton-Greenspan's policy mix, it is obvious that Lebanese Central Bank cannot compensate negative effects of governments' restrictive policies. The main reason is the adoption of a fixed exchange rate between Lebanese lira and US dollar. Increasing interest rate killed personal initiatives and small businesses in the Lebanese economy. Consequently, Lebanese economy is blocked in a fiscal vicious circle due to low production and thus low tax amounts leading to a continuous fiscal deficit.

\section{Mundell's Incompatibility Triangle}

Robert Mundell developed core macroeconomic objectives represented in three angles of its incompatibility triangle. Robert Mundell argued that one cannot have, at the same time, fixed exchange rate, free international circulation of capital and autonomous monetary policy [7]. Free international circulation of capital is one of the most important economic and social factors for Lebanese citizens due to huge amounts provided from Lebanese immigrants. In addition, Lebanese Central Bank sacrificed the autonomy of the monetary policy via a high interest rate ensuring stability of the fixed exchange rate adopted since 1992. Referring to Mundell's triangle, the Lebanese economy sacrificed the autonomy of its monetary policy for a fixed exchange rate as transposed in Figure 3.

IMF report on exchange rate regimes [8] considered Lebanese exchange rate as a conventional fixed PEG to single currency very close to be evaluated as a currency board ${ }^{20}$.

The objective of a currency board is to preserve the national currency stability, and control inflation rate. However, even if adopting a fixed PEG seems to be positive in a short term period, decision makers should consider the cost of adopting a dependent monetary policy with a high interest rate [9].

Isn't it time to liberalize exchange rate, regain autonomy of monetary policy to compensate negative consequence of government's restrictive budget policy, decrease interest rate to encourage and boost private macroeconomic investments ${ }^{21}$ ?

Researchers in the IIE ${ }^{22}$ developed in a scientific report the advantages and disadvantages of currency boards.

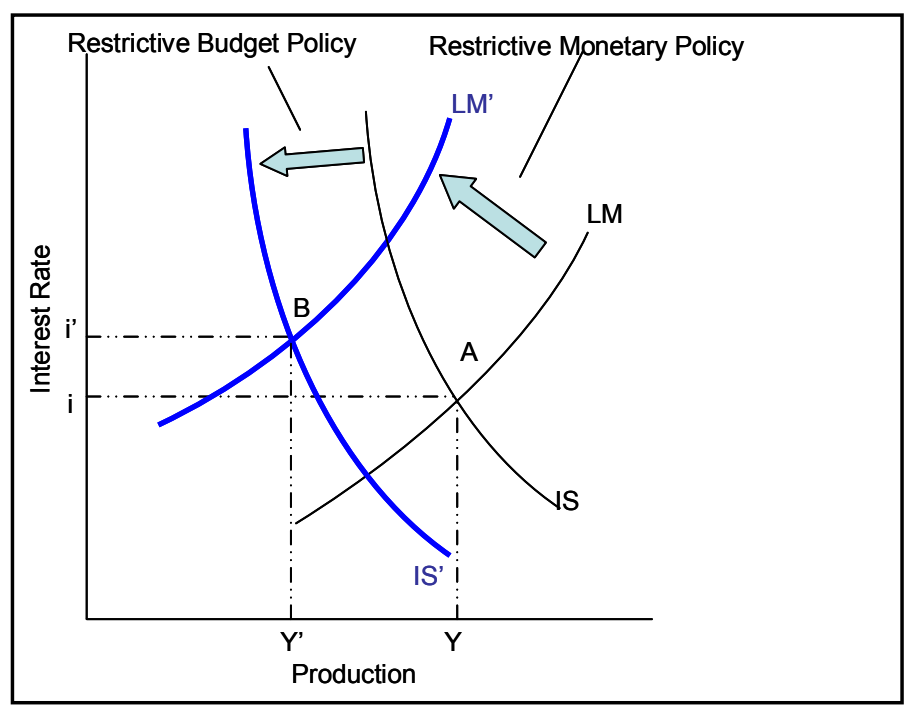

Source: author's transposition of IS-LM on Lebanese policy-mix.

Figure 2. Lebanese policy mix.

\footnotetext{
${ }^{20}$ Currency board is a monetary authority which is required to maintain a fixed exchange rate with a foreign currency. This policy objective requires the conventional objectives of a central bank to be subordinated to the exchange rate target. Under this regime, the domestic currency is backed with foreign reserve currency.

${ }^{21}$ For J.M. Keynes, a high interest rate is the killer of the private macroeconomic investments.

${ }^{22}$ Institute for International Economics.
} 


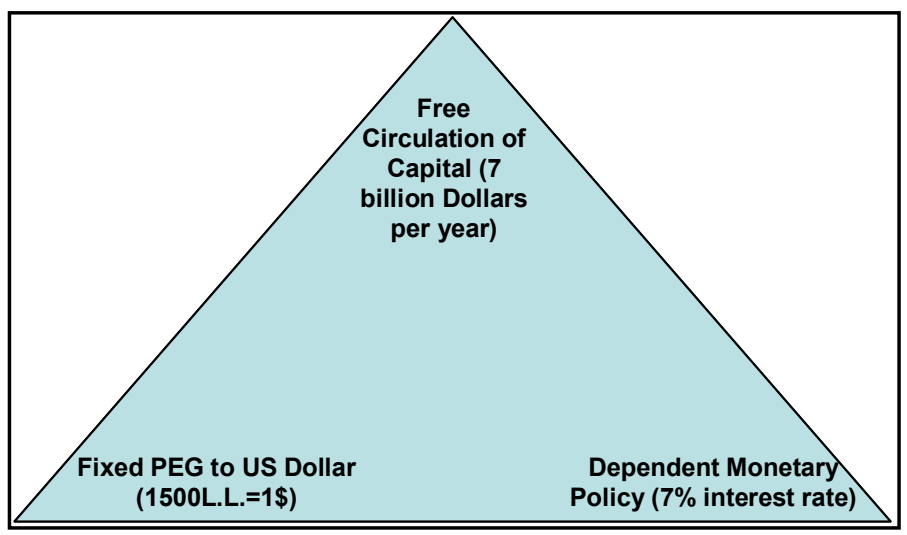

Source: author's transposition of Mundell's triangle on Lebanese monetary indicators.

Figure 3. Lebanese monetary indicators.

\subsection{Advantages of Hard PEGs}

Currency boards are considered one of the hardest PEG regimes that have been implemented in several economies and countries. Their advantages can be summarized in three main arguments:

1) Currency boards can substitute a regulated monetary policy ${ }^{23}$, ensuring price stability which is the main justification for its application. Studies effected by Ghosh, Gulde, and Wolf [10] concluded that currency boards application decreased inflation rate by $4 \%$ lower than other exchange regimes.

2) A strong political commitment to the exchange regime will enable it to deter speculative attacks.

3) Currency boards' application will generate efficient fiscal rules since their laws prohibit direct monetary financing of government expenditures. Ghosh, Gulde, and Wolf [10] found that countries adopting currency boards are running smaller fiscal deficits in comparison with others adopting different exchange regimes. These countries have also lower ratios of governments' expenditures to GDP.

$\mathrm{IMF}^{24}$ researchers analyzed the impact of applying currency boards on fiscal deficits; they concluded that results differed from one country to another.

\subsection{Disadvantages of Hard PEGs}

The Applications of fixed hard Pegs showed different weaknesses, disadvantages and failures:

1) Difficulty in correcting the real exchange rate after over evaluation, due to essential involvement of price level and domestics costs without considering the nominal exchange rate.

2) The Central bank loses its monetary policy independence especially when the reserve currency country is characterized by monetary and economic policies different from the ones adopted in the country adopting the currency board. Argentina was adopting a currency board in 1999 when Unites States decided to increase the interest rate to face the boom in the US economy [9]. Argentina was passing through a recession period and needed a lower interest rate to boost investment. This need was not assured due to the application of currency board. Borensztein, Zettelmeyer, and Philippon [11] compared the autonomy of the monetary policy of two sets of developing countries. Argentina and Hong Kong adopting hard Pegs versus Mexico and Singapore adopting a managed floating exchange rate. They found that interest rates in Hong Kong reacted much more to United States interest rates than in Singapore. While Mexico reacted less than Argentina to US interest rate shocks.

3) Currency boards' application limits the ability of monetary authority in supporting weak financial institutions [12]. Monetary authority cannot increase money supply unless they have important amounts of foreign currency reserves.

4) Currency boards' applications will result in high dollarization rates in bank deposits [12]. In Argentina in 2001, two-thirds of bank deposits were in US dollar, in Lebanon dollarization rates of bank deposits attained $64 \%$ in 2010

\footnotetext{
${ }^{23} \mathrm{~A}$ gold standard without gold.

${ }^{24}$ World economic outlook, May 2001.
} 
To sum-up, countries adopting currency boards will lose their control and the autonomy of their monetary policy in dealing with recession, encouraging investment, decreasing unemployment [13]. Restrictive budget policies to decrease fiscal deficits will not be compensated via an expansionist monetary policy capable of encouraging consumption, demand and productivity [14].

For Lebanon, taking into consideration Mundell's incompatibility triangle and IS-LM curve, the budget policy practiced by successive governments targeting the reduction of the fiscal deficit will indeed have negative results on consumption and investment. A deep economic cooperation with the central bank is necessary to compensate the above mentioned effects. The Central Bank needs to liberalize progressively the exchange rate and switch from hard peg to a managed floating peg on the long term. Meanwhile, monetary authority should start planning to switch to an intermediate fixed peg on a short term, mainly to a crawling peg based on progressive re-evaluation and through a fixed progression of the Lebanese lira from US dollar. A 33\% evaluation can be achieved over two years and will have different effects enhancing purchasing power, decreasing dollarization rate, decreasing interest rate, and boosting private investments. A major benefit from this planned evaluation concerns the decrease of the government's public debt by $17 \%$, knowing that $50 \%$ of it is issued in US dollar.

The unique inconvenient from switching to a forward-looking crawling peg will be the discouragement of the Lebanese exports, and consequently the increase of the trade deficit. On a long term, the investment and productivity will increase; strategic industries will gain national competitive advantage.

Michael Porter's diamond ${ }^{25}$ can be an efficient model to consider for a new trade strategy that enables Lebanese industry to participate actively in the multilateral trade system; this will enable Lebanon to renegotiate its membership in the GAFTA ${ }^{26}$ and the Euro-Med partnership for a better contribution. Accession to the World Trade Organization will be smooth and will progress on solid economic capacities.

Last but not least, the rapid increase of the trade deficit on a short term will not have dangerous consequences on Lebanese economy, since Lebanese balance of payment is achieving a 3.5\% as annual surplus due to huge capital entry sent by Lebanese immigrants.

\section{Conclusions}

International organizations usually condition their financial support to developing countries by encouraging and urging concerned governments to apply restrictive policy mix focusing exclusively on the financial market via overcoming inflation as the main objective to attain to recover the national economy.

Further to negative results obtained in different countries after practicing liberal and classic policies, mainly the Asian tigers in 1997, Mexico, Brazil and Argentina in the 80s and 90s and Greece in 2010, it is important and urgent to question these economic behaviors.

It is time to re-evaluate intermediate practices closed to liberalism and capitalism. Market regulation, efficient government intervention, and efficient public sector will be alternatives to switch to another century. A century characterized by a new intermediate practice based on government intervention through a system vision of the national economy. All markets should have the same priority for government policies. Inflation should not be seen as the unique and major problem to our economies. Interdependence between goods and services, financial and labor markets has to be the major concern of any policy mix adopted by developing countries' governments.

For Lebanon, a new policy mix for an economic recovery needs to be elaborated and applied in order to avoid additional structural economic weaknesses.

The following steps to be considered as essential starting points:

$\Rightarrow$ Switch to an intermediate fixed peg, and later to a managed floating exchange rate.

$\Rightarrow$ Regain the autonomy of the monetary policy by decreasing interest rate to boost consumption and investment.

$\Rightarrow$ Government's support for strategic industries capable to participate effectively in the international multilateral trade system.

$\Rightarrow$ Market regulation through efficient government intervention in controlling price, quality and market competition.

$\Rightarrow$ Adjustment of the fiscal policy by reducing tax rates and increasing tax amounts by defeating private and

\footnotetext{
${ }^{25}$ Porter's diamond is based on four sets of attributes: created factors of production, demand conditions in the home market, related and supported industries, firm strategy.

${ }^{26}$ Greater Arab Free Trade Agreement.
} 
public corruption.

$\Rightarrow$ Long term plan to pay back the public debt through serious negotiation with local banks.

$\Rightarrow$ Privatize inefficient and unproductive public administrations after detailed feasibility studies showing either advantages or inconveniences of each privatization.

\section{References}

[1] Boltanski, L. and Chiappello, E. (1999) Le Nouvel Esprit du Capitalisme. Gallimard, Paris. http://www.imf.org/external/pubs/nft/op/171/

[2] Notermans, T. (2000) Money, Markets and the State. Social Democratic Economic Policies since 1918, Cambridge University Press, Cambridge, 302. http://dx.doi.org/10.1017/CBO9780511521607

[3] Verley, P. (1997) L'échelle du Monde. Gallimard, Paris.

[4] Verley, P. (2005) Note critique. Encore L'Industrialisation Belge au XIXe Siècle: À Propos de Quelques Travaux Récents. Revue d'Histoire du XIXe Siècle, 31, 117-142.

[5] Mankiw, G. (2009) Macroéconomie. 4th Edition, De Boeck, Paris.

[6] Presidency of the Council of Ministers (2010) Economic Accounts of Lebanon, 2009. http://www.finance.gov.lb/en-US/finance/EconomicDataStatistics/Pages/LatestEconomicIndicators.aspx

[7] Blanchard, O. and Cohn, D. (2006) Macroéconomie. 4th Edition, Pearson, Paris.

[8] Bubula, A. and Ölker-Robe, İ. (2002) The Evolution of Exchange Rate Regimes since 1990: Evidence from de Facto Policies. IMF Working Paper. http://www.imf.org/external/pubs/ft/wp/2002/wp02155.pdf

[9] Collins, S.M. (1996) On Becoming More Flexible: Exchange Rate Regimes in Latin American and the Caribbean. Journal of Development Economics, 51, 117-138. http://dx.doi.org/10.1016/S0304-3878(96)00428-2

[10] Ghosh, A.R., Gulde, A.-M. and Wolf, H.C. (1998) Currency Boards: The Ultimate Fix? IMF Working Paper. http://www.imf.org/external/pubs/ft/wp/wp9808.pdf

[11] Borensztein, E., Zettelmeyer, J. and Philippon, T. (2001) Monetary Independence in Emerging Markets: Does the Exchange Rate Regime Make a Difference? IMF Working Paper. http://www.imf.org/external/pubs/ft/wp/2001/wp0101.pdf

[12] Obstfeld, M. and Rogoff, K. (1995) The Mirage of Fixed Exchange Rates. Journal of Economic Perspectives, 9, 73-96. http://dx.doi.org/10.1257/jep.9.4.73

[13] Ghosh, Gulde and Wolf (2000) On the Historical Record of Exits from Currency Boards.

[14] Baliño, T., Bennett, A. and Borensztein, E. (1999) Monetary Policy in Dollarized Economies. IMF Occasional Paper. http://www.imf.org/external/pubs/nft/op/171/ 